\title{
Effect of Container Design on Plant Growth and Root Deformation of Littleleaf Linden and Field Elm
}

\author{
Gabriele Amoroso ${ }^{1}$, Piero Frangi, and Riccardo Piatti \\ Fondazione Minoprio, Centro MiRT, Viale Raimondi, 54, 22070 Vertemate \\ con Minoprio (CO), Italy
}

Francesco Ferrini and Alessio Fini

Department of Plant, Soil and Environmental Science, University of Florence, Viale delle Idee, 30, 50019 Sesto Fiorentino (FI), Italy

\section{Marco Faoro \\ Fondazione Minoprio, Centro MiRT, Viale Raimondi, 54, 22070 Vertemate con Minoprio (CO), Italy}

Additional index words. nursery stock quality, root defects, seedling, Tilia cordata, Ulmus minor

\begin{abstract}
This experiment investigated the effect of different container design on growth and root deformation of littleleaf linden (Tilia cordata Mill.) and field elm (Ulmus minor Mill.). The trial was carried out over two growing seasons (2008 to 2009). In April 2008, 1-year-old bare-root seedlings of the two species were potted in three types of 1-L containers: Superoots $^{\circledR}$ Air-Cell $^{\mathrm{TM}}$ (The Caledonian Tree Company, Pathhead, UK), Quadro fondo rete (Bamaplast, Massa e Cozzile, Italy), and smooth-sided containers. At the beginning of the second growing season, the same plants were repotted in the following 3-L containers: Superoots ${ }^{\circledR}$ Air-Pot $^{\text {TM }}$ (The Caledonian Tree Company), Quadro antispiralizzante (Bamaplast), and smooth-sided containers. At the end of each growing season, a subset of the plants from each container type was harvested to determine shoot and root dry mass and root deformation (by dry weight of root deformed mass relative to the whole root mass). Chlorophyll fluorescence and leaf chlorophyll content were measured during the second growing season. For both species, at the end of first growing season, the poorest root architecture was observed in the smooth-sided containers, whereas Superoots ${ }^{\circledR}$ Air-Cell ${ }^{\mathrm{TM}}$ and Quadro fondo rete both reduced the percentage of deformed root mass. At the end of the second growing season, plants of both species grown in Superoots ${ }^{\circledR}$ Air-Pot $^{\mathrm{TM}}$ showed less deformed root mass, whereas Quadro antispiralizzante provided good results only in littleleaf linden. A reduction of field elm root biomass and littleleaf linden shoot biomass was observed at the end of the trial in plants grown in Superoots ${ }^{\circledR}$ Air-Pot $^{\circledR}$. Plants grown in these containers showed less leaf chlorophyll content compared with plants grown in smooth-sided containers at the end of the second year.
\end{abstract}

Nursery container design affects posttransplant growth of several species (Arnold and McDonald, 2006; Gilman, 2001; Struve, 1993). Plants grown in smooth-sided plastic containers for a long production cycle result in deformed roots (Gilman et al., 2003; Ruter, 1994) because lateral roots cannot extend horizontally and therefore they either circle

Received for publication 14 Sept. 2010. Accepted for publication 19 Oct. 2010.

This work was conducted under a research project, "Razionalizzazione delle tecniche vivaistiche in pieno campo ed in contenitore-TECVIVA," financed by Regione Lombardia-Agricultural Department according to the Plan of Research and Development 2007.

We gratefully acknowledge Professor Daniel K. Struve (Department of Horticulture and Crop Science, The Ohio State University) for his critical review of the manuscript.

${ }^{1}$ To whom reprint requests should be addressed; e-mail g.amoroso@fondazioneminoprio.it. within the container or grow vertically to the bottom (Lindström and Rüne, 1999). The impact of an unevenly spread and undistributed root system on the juvenile anchorage of a tree is well documented (Balisky et al., 1995; Lindgren and Örlander, 1978; Lindström and Håkansson, 1995). Deformed root systems can contribute to long-term tree growth problems in the landscape such as instability (Nichols and Alm, 1983), reduced shoot growth, tree decline, and mortality (Ortega et al., 2001, 2006). Tree survival and growth after outplanting are directly related to the ability of the root system to rapidly produce new roots that will grow into the surrounding soil; thus, plants are highly affected by initial shoot and root morphology (Paz, 2003; Schultz and Thompson, 1997; Tsakaldimi et al., 2005). Circling roots developing at the bottom of a container commonly fail to grow into the soil profile resulting in reduced root growth. Root deformation is common in plug-grown seedlings after plant- ing (Blanusa et al., 2007; Landis et al., 1990). Loblolly pine (Pinus taeda L.) seedling growth after transplanting was significantly reduced when trees with malformed tap roots were planted (Harrington and Howell, 1998).

Mechanical remediation of circling roots at transplanting has become a standard practice, although correcting root malformation can cause transplant shock during field establishment (Arnold and Struve, 1989; Harris, 1992; Struve, 1993). Despite the short-term stress induced by root pruning, correcting root malformation is critical to successful longterm establishment of container-grown nursery stock (Chalker-Scott, 2005, Franco et al., 2006; Gilman et al., 2002; Kozlowski and Pallardy, 1997). Mechanical remediation of circling roots is typically accomplished at transplanting by making several cuts on the root ball periphery or splitting and splaying the bottom two-thirds of the root ball (butterfly pruning) (Gouin, 1983; Harris, 1992). Recently, root shaving has been introduced as a method of correcting root malformations (Gilman et al., 2010b).

To reduce the incidence of deformed roots induced during container production, many alternative container types have been designed (Appleton and Whitcomb, 1983, Gilman et al., 2010a). These containers use air root pruning, specialized container shapes, bottomless containers, woven or non-woven fabrics, mechanical deflection, or chemicals to control root growth (Brass et al., 1996; Gilman et al., 2003; Marshall and Gilman, 1998). Several studies indicate that these methods can improve the root system architecture avoiding mechanical root pruning at planting and long-term problems on plant growth (Arnold, 1996; Gilman et al., 2010b; Marshall and Gilman, 1998; Struve, 1993; Tsakaldimi et al., 2005; Tsakaldimi and Ganatsas, 2006).

When porous-walled plastic containers are used, root growth is stopped at the wallsubstrate interface (Privett and Hummel, 1992): the tip roots reach the container wall hole and are desiccated (air-pruning). As a result of the loss of root apical dominance, more fine roots develop in the inner part of the root ball, allowing a more even root system (Marler and Willis, 1996). Air-pruning technology can be combined with mechanical deflection by including vertical ribs on the interior container surfaces (Rune, 2003).

Field elm and littleleaf linden are two widespread woody plants in Italy; however, no study about the influence of container typology on root conformation of these two species has been reported in the literature. Thus, the objective of this experiment was to evaluate the effect of three different containers on plant growth and root architecture of these two species. To provide further insight on the effect of container shape on plant stress, chlorophyll content and chlorophyll fluorescence were also studied.

\section{Materials and Methods}

First year experiment. The study was carried out in an experimental nursery at the 
Fondazione Minoprio located in Vertemate con Minoprio (Como, Italy; lat. 45 $44^{\prime} \mathrm{N}$, long. $9^{\circ} 04^{\prime}$ E, elevation $\left.342 \mathrm{~m}\right)$. A hoophouse $(2.5 \mathrm{~m}$ tall in the middle) covered with antihail netting ( $10 \%$ of photosynthetically active radiation reduction) was used to grow the plants. Overhead irrigation was applied daily to maintain water content of the containers at near $100 \%$ waterholding capacity according to Sammons and Struve (2008). Irrigation was not supplied when rainfall exceeded $15 \mathrm{~mm}$ during a 24-h period.

One-year-old bare root seedlings of littleleaf linden and field elm purchased from a commercial nursery were used. Container substrate consisted of a $4: 1(\mathrm{v} / \mathrm{v})$ mixture of sphagnum peat and pumice amended with $4 \mathrm{~kg} \cdot \mathrm{m}^{-3}$ of calcium carbonate; a controlledrelease fertilizer, Ficote ${ }^{\circledR}(15 \mathrm{~N}-3.5 \mathrm{P}-10 \mathrm{~K} ; 8$ to 9 -months formulation at $20{ }^{\circ} \mathrm{C}$; Scotts, Marysville, $\mathrm{OH}$ ), was preincorporated at the rate of $4 \mathrm{~kg} \cdot \mathrm{m}^{-3}$. Weeds were controlled by periodic hand weeding.

In April 2008, plants were potted in three different 1-L containers filled with $0.9 \mathrm{~L}$ substrate (Fig. 1). No roots were pruned at planting. Containers tested were: 1) smoothsided square container (Stop quadro; ARCA spa, Osio Sotto, Italy); 2) Superoots ${ }^{\circledR}$ AirCell $^{\mathrm{TM}}$ (The Caledonian Tree Company, Pathhead, UK), a container characterized by cuspated walls made up of closed inward pointing cones and open-ended outward pointing cones and the container bottom consisted of a plastic net $(1 \mathrm{~cm} \times 1 \mathrm{~cm}) ; 3)$ Quadro fondo rete (Bamaplast, Massa e Cozzile, Italy), a square container with eight vertical interior ribs (two ribs per container wall) and a plastic net bottom $(0.5 \mathrm{~cm} \times 0.5 \mathrm{~cm})$. Containers used were made of black plastic.

The experiment was set as a complete randomized block design. There were 40 containers in each of 12 blocks for a total of 480 plants per species. Within each block, con-

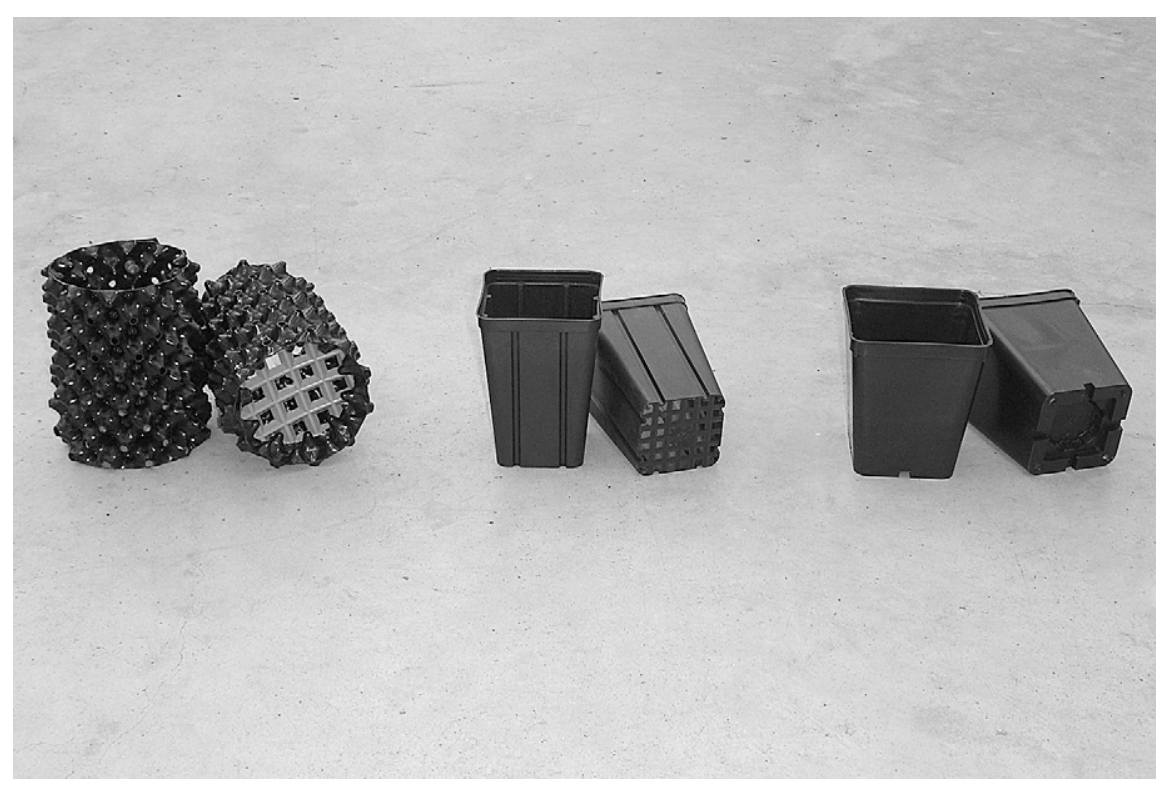

Fig. 1. From left to right (1-L containers): Superoots ${ }^{\circledR}$ Air-Cell ${ }^{\mathrm{TM}}$ (The Caledonian Tree Company, Pathhead, UK), Quadro fondo rete (Bamaplast, Massa e Cozzile, Italy), and smooth-sided square container (Stop quadro; ARCA spa, Osio Sotto, Italy).

tainers were arranged in eight rows of five plants at a density of 25 plants $/ \mathrm{m}^{2}$.

Plant growth and root morphology were determined at the end of the growing season (Sept. 2008) on five plants per block and species, a total of 60 plants per species. Substrate was removed from the roots using compressed air; after cleaning, for each root, when deformations were detected (i.e., circling or ascending parts), the deformed root part was manually separated from the non-deformed root part at the first point of deflection. For each plant deformed roots, non-deformed roots and aboveground parts were oven-dried separately $\left(104{ }^{\circ} \mathrm{C}\right)$ until constant weight $(\approx 72 \mathrm{~h})$, and then dry weights were recorded. The percentage of deformed root mass relative to the entire root mass was used as the determinate of root system quality where low deformed root percentage indicates a highquality root system.

Percentage values were transformed through the formula: arcsine $\sqrt{x}$ (where $\mathrm{x}$ is the percentage value divided by 100) before data were subjected to one-way analysis of variance using SPSS ${ }^{\circledR}$ statistical package for Windows (Version 17.0; SPSS Inc., Chicago, IL). Data from the two species were analyzed independently. Differences between means were declared statistically different using Duncan's multiple range test $(P \leq 0.05)$.

Second year experiment. The trial was carried out in the same hoophouse using similar cultural practices. Plants grown in 1-L containers during the first growing season were repotted into a similar type but larger containers (3 L) in May 2009 (Fig. 2). Three-liter Quadro antispiralizzante (Bamaplast), characterized by a square shape, four vertical ribs on the inside walls, and a wholly closed plastic bottom, was used instead of the 1-L Quadro fondo rete; a 3-L circular smoothsided container (Cultistop; ARCA spa) was 
the second growing season (when plants were grown into 3-L containers), littleleaf linden grown in traditional smooth-sided containers continued showing the highest percentage of

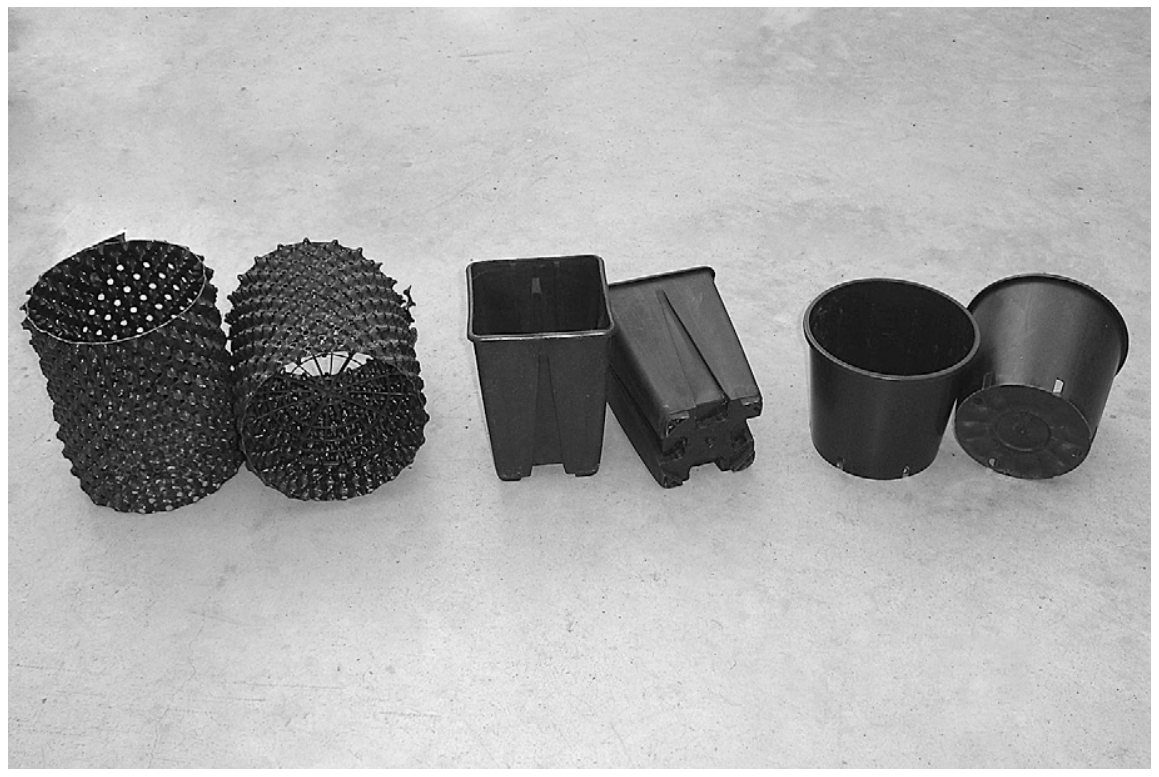

Fig. 2. From left to right (3-L containers): Superoots ${ }^{\circledR}$ Air-Pot $^{\mathrm{TM}}$ (The Caledonian Tree Company, Pathhead, UK), Quadro antispiralizzante (Bamaplast, Massa e Cozzile, Italy), and circular smoothsided container (Cultistop; ARCA spa, Osio Sotto, Italy).

Table 1. Shoot and root dry biomass ( $\mathrm{g}$ ) and percentage of deformed roots on relative to total root biomass $(\mathrm{w} / \mathrm{w})$ in littleleaf linden and field elm seedlings grown for one season (2008) in three 1-L containers.

\begin{tabular}{|c|c|c|c|}
\hline Species and container typology & Shoot biomass (g) & Root biomass (g) & Deformed roots $(\%)$ \\
\hline \multicolumn{4}{|l|}{ Littleleaf linden } \\
\hline Superoots $^{\circledR}$ Air-Cell $^{\mathrm{TM}}$ & 12.7 & $14.6 \mathrm{a}^{\mathrm{z}}$ & $13.2 \mathrm{~b}$ \\
\hline Quadro fondo rete & 13.7 & $11.4 \mathrm{~b}$ & $15.1 \mathrm{~b}$ \\
\hline Smooth-sided square container & 11.9 & $14.0 \mathrm{a}$ & $26.2 \mathrm{a}$ \\
\hline Significance & NS & $*$ & $* *$ \\
\hline \multicolumn{4}{|l|}{ Field elm } \\
\hline Superoots $^{\circledR}$ Air-Cell $^{\mathrm{TM}}$ & 13.4 & 9.5 & $11.3 \mathrm{~b}$ \\
\hline Quadro fondo rete & 12.8 & 9.0 & $17.1 \mathrm{~b}$ \\
\hline Smooth-sided square container & 12.5 & 8.8 & $26.8 \mathrm{a}$ \\
\hline Significance & NS & NS & ** \\
\hline
\end{tabular}

${ }^{\mathrm{z}}$ For each species, means within the same column followed by different letters are significantly different from each other using the Duncan's mean separation test.

Ns, $*, * *, * * *$ indicates non-significant, significant at $P \leq 0.05, P \leq 0.01, P \leq 0.001$, respectively.

Table 2. Shoot and root dry biomass ( $\mathrm{g}$ ) and percentage of deformed roots on relative to total root biomass $(\mathrm{w} / \mathrm{w})$ in littleleaf linden and field elm seedlings grown for two seasons (2008 to 2009) in different containers. $^{\text {z }}$

\begin{tabular}{lccc}
\hline Species and container typology & Shoot biomass $(\mathrm{g})$ & Root biomass $(\mathrm{g})$ & Deformed roots (\%) \\
\hline Littleleaf linden $^{\mathrm{y}}$ & & & \\
Superoots $^{\circledR}$ Air-Pot & & \\
Quadro antispiralizzante & $35.9 \mathrm{~b}^{\mathrm{x}}$ & 38.7 & $18.3 \mathrm{~b}$ \\
$\quad$ Circular smooth-sided container & $47.1 \mathrm{a}$ & 40.8 & $19.3 \mathrm{~b}$ \\
Significance & $41.9 \mathrm{a}$ & 40.7 & $34.6 \mathrm{a}$ \\
Field elm & $* *$ & $\mathrm{NS}$ & $* * *$ \\
Superoots & & & \\
Quadro antispiralizzante & 66.6 & $39.4 \mathrm{~b}$ & $25.0 \mathrm{c}$ \\
Circular smooth-sided container & 76.1 & $50.4 \mathrm{a}$ & $48.0 \mathrm{~b}$ \\
Significance & 77.9 & $44.7 \mathrm{ab}$ & $58.9 \mathrm{a}$ \\
\hline
\end{tabular}

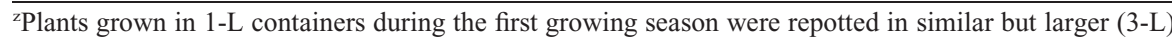
containers at the beginning of the second growing season (2009).

${ }^{\mathrm{y}}$ In the 2009 growing season, Superoots ${ }^{\circledR}$ Air-Pot ${ }^{\mathrm{TM}}$; Quadro antispiralizzante and circular smooth-sided containers were used instead of Superoots ${ }^{\circledR}$ Air-Cell ${ }^{\mathrm{TM}}$, Quadro fondo rete, and square smooth-sided containers, respectively.

${ }^{x}$ For each species, means within the same column followed by different letters are significantly different from each other using the Duncan's mean separation test.

Ns, ${ }^{*}, * *, * * *$ indicates non-significant, significant at $P \leq 0.05, P \leq 0.01, P \leq 0.001$, respectively.
Our study show that air-pruning technology and mechanical impediments on the inside walls of container can be a useful tool to limit root deformation in container-grown littleleaf linden. The positive effect of airpruning on root system architecture was also reported by Moore (2001) for Australian tree species grown in 20-cm diameter Superoots ${ }^{\circledR}$ Air-Pot ${ }^{\mathrm{TM}}$, whereas Marler and Willis (1996) reported that air-root pruning containers (RootBuilder $^{\circledR}$ panels; Lacebark, Inc., Stillwater, OK) produced a more fibrous root system than conventional containers.

Shoot biomass was unaffected by the container design at the end of the first growing season (Table 1), whereas at the end of the second season, the lowest value was observed on plants grown in Superoots ${ }^{\circledR}$ Air-Pot $^{\mathrm{TM}}$ (Table 2). At the end of the first year, the lowest root biomass was observed in plants grown in Quadro fondo rete (Table 1), whereas no differences were observed between plants grown in traditional container and Superoots ${ }^{\circledR}$ Air-Cell ${ }^{\mathrm{TM}}$. Root biomass at the end of the second year was unaffected by the container typology (Table 2). As reported by Ortega et al. (2006), seedlings grown in containers that permit air pruning had less growth and lower biomass production. This can be attributed to the moderate plant stress resulting from root tip replacement associated with new root regeneration. Moreover, Superoots ${ }^{\circledR}$ containers are designed to introduce air into substrate through both container walls and bottom net, whereas Quadro antispiralizzante is air-opened through the bottom net. This allows more water to evaporate from the substrate periphery (Arnold and McDonald, 2006; Owen and Stoven, 2008). As reported by Amoroso et al. (2010), a dry substrate is warmer in comparison with a well-watered substrate during the day, and this can lead to plant stress. Root tip replacement in plants grown in Superoots ${ }^{\circledR}$ Air-Pot ${ }^{\mathrm{TM}}$ and water evaporation through the open-air container walls could explain the observed lower plant growth.

In littleleaf linden, the container type did not affect chlorophyll content or chlorophyll fluorescence $(\mathrm{Fv} / \mathrm{Fm})$, except on 11 Aug. when plants grown in Superoots ${ }^{\circledR}$ Air-Pot ${ }^{\mathrm{TM}}$ showed a lower chlorophyll content compared with plants grown in smooth-sided containers (Table 3). Indeed, the leaves of these plants were more yellow and senescent. This finding can also be explained by the moderate plant stress resulting from porous walls and bottom in Superoots ${ }^{\circledR}$ Air-Pot ${ }^{\mathrm{TM}}$ containers. At every assessment, no differences in chlorophyll content were observed between plants grown in Quadro antispiralizzante and smooth-sided containers (Table 3 ). In this species, the polyphasic shape of the cholorophyll $a$ fluorescence was unaffected by the container design at each assessment (thus, only the last measurement is reported in Figure 3).

Field elm. Also in this species, root architecture was affected by the container design by the end of the first growing season, when plants were grown in 1-L containers (Fig. 4). Plants grown in traditional smooth-sided containers 
had poorer root architecture in comparison with plants grown in Superoots ${ }^{\circledR}$ Air-Cell $^{\mathrm{TM}}$ and Quadro fondo rete containers (Table 1). At the end of the second growing season, field elm grown in traditional smooth-sided containers showed the highest percentage of deformed roots, whereas plants grown in Superoots ${ }^{\circledR}$ Air-Pot ${ }^{\mathrm{TM}}$ had significantly lower root deformation compared with field elm grown in Quadro antispiralizzante (Table 2). The vigorous root system of this species can explain the lower effect of Quadro antispiralizzante on root architecture in comparison with Superoots ${ }^{\circledR}$ Air-Pot ${ }^{\mathrm{TM}}$; indeed, as reported by Lindström (1994) and Lindström and Håkansson (1995), plants with a vigorous root system (i.e., Pinus spp.) grown in containers with vertical interior ribs reduced root spiraling when compared with plants grown in traditional smooth-walled containers but offered limited improvement in root structure.

Table 3. Chlorophyll content (Chl, unit SPAD) and chlorophyll fluorescence (Fv/Fm) in littleleaf linden grown in three different containers.

\begin{tabular}{|c|c|c|c|c|c|c|}
\hline \multirow[b]{2}{*}{ Container typology } & \multicolumn{2}{|c|}{25 June 2009} & \multicolumn{2}{|c|}{17 July 2009} & \multicolumn{2}{|c|}{11 Aug. 2009} \\
\hline & Chl & $\mathrm{Fv} / \mathrm{Fm}$ & Chl & $\mathrm{Fv} / \mathrm{Fm}$ & Chl & $\mathrm{Fv} / \mathrm{Fm}$ \\
\hline Superoots $^{(\circledast)}$ Air-Pot ${ }^{\mathrm{TM}}$ & 32.4 & 0.787 & 33.8 & 0.793 & $31.8 \mathrm{~b}^{\mathrm{z}}$ & 0.741 \\
\hline Quadro antispiralizzante & 33.9 & 0.783 & 34.3 & 0.799 & $32.2 \mathrm{ab}$ & 0.752 \\
\hline Circular smooth-sided container & 34.5 & 0.772 & 37.4 & 0.795 & $35.7 \mathrm{a}$ & 0.744 \\
\hline Significance & NS & NS & NS & NS & $*$ & NS \\
\hline
\end{tabular}

${ }^{\mathrm{z}}$ Means within a column followed by different letters are significantly different from each other using the Duncan mean separation test.

Ns, * indicates non-significant, significant at $P \leq 0.05$, respectively.

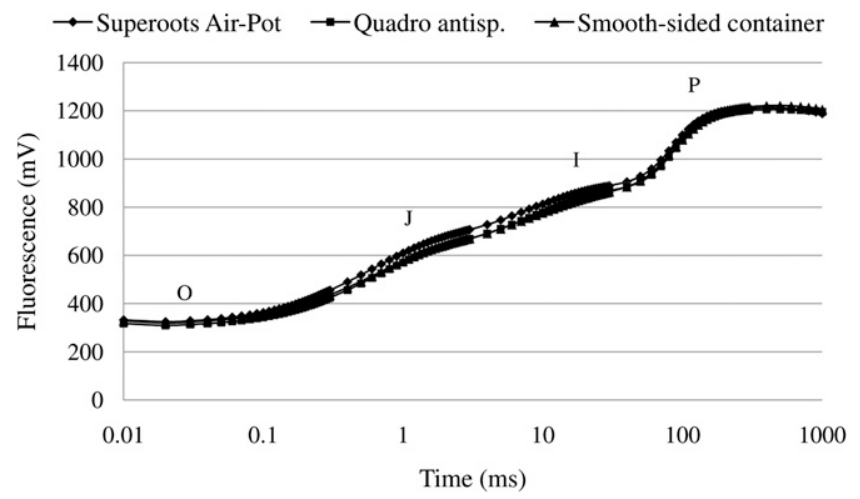

Fig. 3. Chlorophyll $a$ fluorescence induction curves in littleleaf linden grown in three different containers Data collected on 11 Aug. 2009. Each single curve represents the average of 20 independent chlorophyll fluorescence measurements.
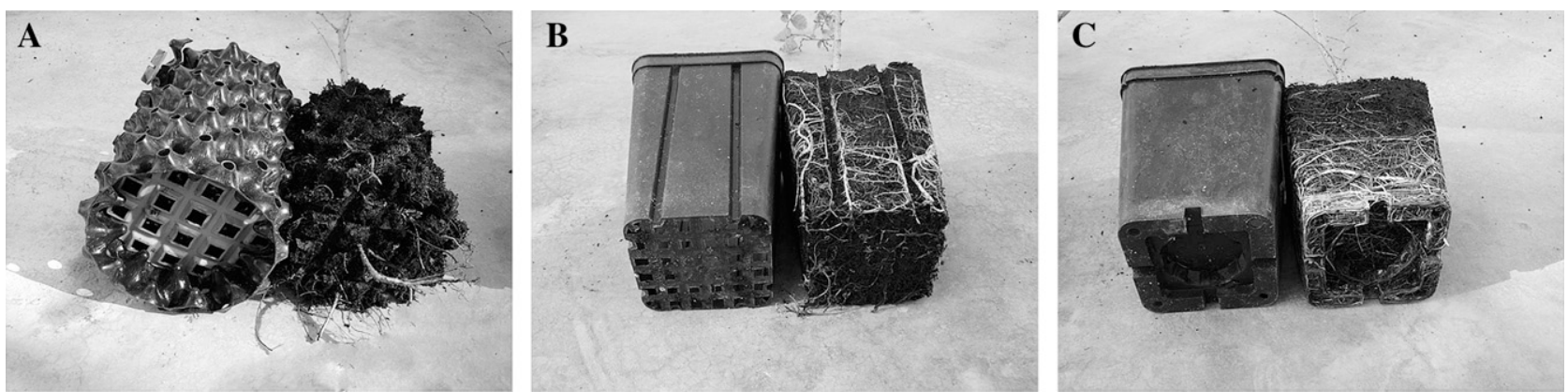

Fig. 4. (A) Rootball of field elm grown in 1-L Superoots ${ }^{\circledR}$ Air-Cell ${ }^{\mathrm{TM}}$ (The Caledonian Tree Company, Pathhead, UK) at the end of the growing season. (B) Rootball of field elm grown in 1-L Quadro fondo rete (Bamaplast, Massa e Cozzile, Italy) at the end of the growing season. (C) Rootball of field elm grown in 1-L smooth-sided square container (Stop quadro; ARCA spa, Osio Sotto, Italy) at the end of the growing season.

HortSCIENCE Vol. 45(12) DeCEMber 2010 ture, $\mathrm{Fv} / \mathrm{Fm}$ ratio is a reliable indicator of the occurrence of environmental stresses, including water stress, on PS II of several woody and herbaceous species (Angelopulos et al., 1996; Lazár, 2006; Maxwell and Johnson 2000; Percival, 2005; Percival and Fraser, 2001; Percival et al., 2006; Yamada et al., 1996). This finding was also confirmed by OIJP chlorophyll $a$ fluorescence transients, which provided evidence that field elm grown in Superoots ${ }^{\circledR}$ Air-Pot ${ }^{\mathrm{TM}}$ was more stressed at the end of the growing season, showing moderate changes in the redox state of plastoquinone (JI-phase) and of the acceptor side of PSI (IP-phase) (Fig. 5) (Tóth et al., 2007). The polyphasic shape of the cholorophyll $a$ fluorescence was unaffected by the container design in the two previous assessments (data not shown).

\section{Conclusion}

The results of this study suggest that the container typology has a strong influence on root system conformation in the two tested species. Plants grown in traditional smoothsided containers showed the highest percentage of deformed roots compared with plants grown in containers with air-pruning or mechanical impediments. As reported in the literature, a poor root conformation can seriously reduce seedling quality after outplanting in several species (Day and Parker, 1997; Landis et al., 1990; Lindström and Håkansson, 1995; Tsakaldimi et al., 2005). In contrast, a welldeveloped and well-structured root system is an essential attribute of quality of seedlings (Day and Parker, 1997; Tsakaldimi et al., 2005). Moreover, as suggested by Livingston (1990), another negative effect of root deformation is deteriorated plant vitality resulting from root disease caused by fungal infections. Finally, the ultimate consequence of root deformation can be an uprooting resulting from weak root anchorage (Lindström and Håkansson, 1995). The moderate lower root biomass observed at the end of the experiment in field elm grown in Superoots ${ }^{\circledR}$ containers can be repaid by a better plant root quality. To obtain field elm or littleleaf linden characterized by a well-structured root system, the use of traditional smooth-sided containers should be avoided in the nursery 
Table 4. Chlorophyll content (Chl, unit SPAD) and chlorophyll fluorescence (Fv/Fm) in field elm grown in three different containers. ${ }^{\mathrm{z}}$

\begin{tabular}{|c|c|c|c|c|c|c|}
\hline \multirow[b]{2}{*}{ Container typology } & \multicolumn{2}{|c|}{8 July 2009} & \multicolumn{2}{|c|}{7 Aug. 2009} & \multicolumn{2}{|c|}{6 Oct. 2009} \\
\hline & Chl & $\mathrm{Fv} / \mathrm{Fm}$ & Chl & $\mathrm{Fv} / \mathrm{Fm}$ & Chl & $\mathrm{Fv} / \mathrm{Fm}$ \\
\hline Superoots $^{\mathbb{R}}$ Air-Pot ${ }^{\mathrm{TM}}$ & $39.7 \mathrm{a}^{\mathrm{y}}$ & 0.783 & 36.7 & 0.761 & $34.6 \mathrm{~b}$ & $0.798 \mathrm{~b}$ \\
\hline Quadro antispiralizzante & $38.8 \mathrm{a}$ & 0.768 & 39.0 & 0.750 & $40.0 \mathrm{a}$ & $0.811 \mathrm{ab}$ \\
\hline Circular smooth-sided container & $34.6 \mathrm{~b}$ & 0.779 & 36.5 & 0.762 & $40.4 \mathrm{a}$ & $0.823 \mathrm{a}$ \\
\hline Significance & * & NS & NS & NS & ** & ** \\
\hline
\end{tabular}

${ }^{\mathrm{z}}$ Data collected three times during the second growing season.

${ }^{y}$ Means within a column followed by different letters are significantly different from each other using the Duncan mean separation test.

Ns, *, ** indicates non-significant, significant at $P \leq 0.05, P \leq 0.01$ respectively.

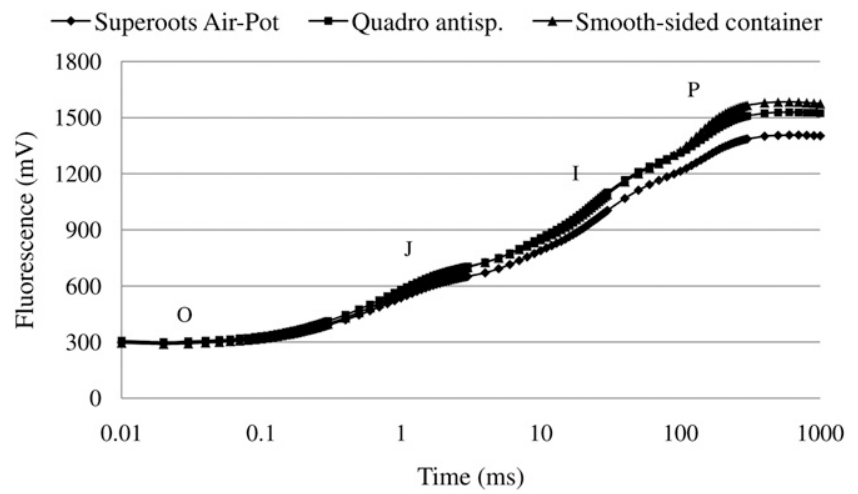

Fig. 5. Chlorophyll $a$ fluorescence induction curves in field elm grown in three different containers. Data collected on 6 Oct. 2009. Each single curve represents the average of 20 independent chlorophyll fluorescence measurements.

phase. However, transplanting studies need to be conducted to determine if higher plant root quality increases transplant success or speeds establishment in the tested species.

\section{Literature Cited}

Amoroso, G., P. Frangi, R. Piatti, A. Fini, and F. Ferrini. 2010. Effect of mulching on plant and weed growth, substrate water content, and temperature in container-grown giant arbovitae. HortTechnology (in press).

Angelopulos, K., B. Dichio, and C. Xiloyannis. 1996. Inhibition of photosynthesis in olive trees (Olea europaea L.) during water stress and rewatering. J. Expt. Bot. 47:1093-1100.

Appleton, B.L. and C.E. Whitcomb. 1983. Effects of container size and transplanting date on the growth of tree seedlings. J. Environ. Hort. 1: 89-93.

Arnold, M.A. 1996. Mechanical correction and chemical avoidance of circling roots differentially affect post-transplant root regeneration and field establishment of container-grown shumard oak. J. Amer. Soc. Hort. Sci. 121:258-263.

Arnold, M.A. and G.V. McDonald. 2006. Shrub rose response to production in smart pots and conventional containers using two contrasting substrates. Subtropical Plant Science J. of the Rio Grande Valley Hort. Soc. 58:1-4.

Arnold, M.A. and D.K. Struve. 1989. Growing green ash and red oak in $\mathrm{CuCO}_{3}$-treated containers increases root generation and shoot growth following transplant. J. Amer. Soc. Hort. Sci. 114:402-406.

Balisky, A.C., P. Salonius, C. Walli, and D. Brinkman. 1995. Seedling roots and forest floor: Misplaced and neglected aspects of British Columbia's reforestation effort. For. Chron. 71:9-65.

Blanusa, T., E. Papadogiannakis, R. Tanner, and R.W.F. Cameron. 2007. Root pruning as a means to encourage root growth in two ornamental shrubs, Buddleja davidii 'Summer Beauty' and Cistus 'Snow Fire'. J. Hort. Sci. Biot. 82:521528.

Brass, T.J., G.J. Keever, D.J. Eakes, and C.H Gilliam. 1996. Styrene-lined and copper-coated containers affect production and landscape establishment of red maple. HortScience 31:353356.

Chalker-Scott, L. 2005. Will the patient live? Amer. Nurse 201:20-23.

Day, D.C. and W.C. Parker. 1997. Morphological indicators of stock quality and field performance of red oak (Quercus rubra L.) seedlings underplanted in a central Ontario. New For. 14:145-156.

Franco, J.A., J.J. Martinez-Sanchez, J.A. Fernandez, and S. Banon. 2006. Selection and nursery production of ornamental plants for landscaping and xerogardening in semi-arid environments. J. Hort. Sci. Biot. 81:3-17.

Gilman, E.F. 2001. Effect of nursery production method, irrigation, and inoculation with mycorrhizae-forming fungi on establishment of Quercus virginiana. J. Arboriculture 29:231-236.

Gilman, E.F., J. Grabosky, A. Stodola, and M.D. Marshall. 2003. Irrigation and container type impact red maple (Acer rubrum L.) 5 years after landscape planting. J. Arboriculture 29: 231-236.

Gilman, E.F., C. Harchick, and M. Paz. 2010a. Effect of container type on root form and growth of red maple. J. Environ. Hort. 28:1-7.

Gilman, E.F., M. Paz, and C. Harchick. 2010b. Root ball shaving improves root system on seven tree species in containers. J. Environ. Hort. 28:13-18.

Gilman, E.F., A. Stodola, and M.D. Marshall. 2002. Root pruning but not irrigation in the nursery affects live oak root balls and digging survival. J. Environ. Hort. 20:122-126.
Gouin, F.R. 1983. Girdling by roots and ropes. J. Environ. Hort. 1:50-52.

Harrington, T.B. and K.D. Howell. 1998. Planting cost, survival, and growth one to three years after establishing loblolly pine seedlings with straight, deformed, or pruned taproots. New For. 15:193-204.

Harris, R.W. 1992. Arboriculture, integrated management of landscape trees, shrubs, and vines. 2nd Ed. Prentice Hall, Englewood Cliffs, NJ. p. 674.

Kozlowski, T.T. and S.G. Pallardy. 1997. Physiology of woody plants. 2nd Ed. Academic Press, San Diego, CA.

Landis, D., R.W. Tinus, S.E. Mc Donald, and J.P. Barnett. 1990. Containers and growing media. Vol. 2. The container tree nursery manual. Agriculture Handbook 674. US Department of Agriculture, Forest Service, Washington, DC. p. 87.

Lazár, D. 2006. The polyphasic chlorophyll a fluorescence rise measured under high intensity of exciting light. Funct. Plant Biol. 33:9-30.

Lindgren, O. and G. Örlander. 1978. A study on root development and stability of 6 to 7 -year old container plants, p. 142-144. In: Van Eerden, E. and J.M. Kinghorn (eds.). Proc. of the Root Form of Planted Trees Symposium. British Columbia Ministry of Forests/Canadian Forestry Service, Joint Report.

Lindström, A. 1994. Stability of young container pine stands. Canadian Silviculture Magazine 2: $16-20$.

Lindström, A. and L. Håkansson. 1995. Going to the root of the evil. Canadian Silviculture Magazine 3:14-17.

Lindström, A. and G. Rüne. 1999. Root deformation in plantations of container-grown Scots pine trees: Effects on root growth, tree stability and stem straightness. Plant Soil 217:29-37.

Livingston, W.H. 1990. Armillaria ostoyae in young spruce plantations. Can. J. For. Res. 20: 1773-1778.

Marler, T.E. and D. Willis. 1996. Chemical or airroot pruning containers improve carambola, longam, and mango seedling root morphology and initial root growth after planting. J. Environ. Hort. 14:47-49.

Marshall, M.D. and E.F. Gilman. 1998. Effects of nursery container type on root growth and landscape establishment of Acer rubrum L. J. Environ. Hort. 15:55-59.

Maxwell, K. and G.N. Johnson. 2000. Chlorophyll fluorescence-A practical guide. J. Expt. Bot. 51:659-668.

Moore, D. 2001. Nursery practices and the effectiveness of different containers on root development. Treenet Proc. of the 2nd National Street Tree Symposium, 6-7 Sept.

Nichols, C.A. and A.A. Alm. 1983. Root development of container-reared, nursery-grown and naturally regenerated pine seedlings. Can. J. For. Res. 13:239-245.

Ortega, U., J. Majada, A. Mena-Petite, J. SanchezZabala, N. Rodriguez-Iturrizar, K. Txarterina, J. Azpitarte, and M. Duñabeitia. 2006. Field performance of Pinus radiata D. Don produced in nursery with different types of containers. New For. 31:97-112.

Ortega, U., N. Rodríguez, C. González-Murua, J. Majada, J. Azpitarte, K. Txarterina, and M. Duñabeitia. 2001. Estudio de la calidad de planta de Pinus radiata en envase, p. 354-359. Montes para la sociedad del Nuevo Milenio. III Congreso Forestal Español. Vol. III. Junta de Andalucía. SE-2499-2001. Consejería de Medio Ambiente. III. 
Owen, J. and H. Stoven. 2008. Searching for the perfect pot. Digger. March:40-45, 57. Oregon Assoc. Nurs., Wilsonville, OR.

Paz, H. 2003. Root/shoot allocation and root architecture in seedlings: Variations among forest sites, microhabitats and successional groups. Biotropica 35:318-332.

Percival, G.C. 2005. The use of chlorophyll fluorescence to identify chemical and environmental stress in leaf tissue of three oak (Quercus) species. J. Arboriculture 31:215-227.

Percival, G.C. and G.A. Fraser. 2001. Measurement of the salinity and freezing tolerance of Crataegus genotypes using chlorophyll fluorescence. J. of Arboriculture 27:233-245.

Percival, G.C., I.P. Keary, and S. Al-Habsi. 2006. An assessment of the drought tolerance of Fraxinus genotype for urban landscape planting. Urban For. Urban Green. 5:17-27.

Percival, G.C., I.P. Keary, and K. Novis. 2008. The potential of a chlorophyll content SPAD meter to quantify nutrient stress in foliar tissue of sycamore (Acer pseudoplatanus), english oak (Quercus robur), and european beech (Fagus sylvatica). Arboriculture \& Urban Forestry 34 : 89-100.

Pinior, A., G. Grunewaldt-Stöcker, H. von Alten, and R.J. Strasser. 2005. Mycorrhizal impact on drought stress tolerance of rose plants probed by chlorophyll $a$ fluorescence, proline content and visual scoring. Mycorrhiza 15:596-605.

Privett, D.W. and R.L. Hummel. 1992. Root and shoot growth of 'Coral Beauty' cotoneaster and Leyland cypress produced in porous and nonporous containers. J. Environ. Hort. 10:133136.

Rune, G. 2003. Slits in container wall improve root structure and stem straightness of outplanted Scots pine seedlings. Silva Fennica 37:333342.

Ruter, J.M. 1994. Growth responses of four vigorousrooted tree species in cupric hydroxide-treated containers. HortScience 29:1089.

Sammons, J.D. and D.K. Struve. 2008. Monitoring effective container capacity: A method for reducing over-irrigation in container production systems. J. Environ. Hort. 26:19-23.

Schultz, R.C. and J.R. Thompson. 1997. Effect of density control and undercutting on root morphology of $1+0$ bareroot hardwood seedlings: Five-year field performance of root-grated stock in the central USA. New For. 13:301-314.

Strasser, R.J., A. Srivastava, and M. TsimilliMichael. 2000. The fluorescence transient as a tool to characterize and screen photosynthetic samples, p. 445-483. In: Yunus, M. (ed.). Prob- ing photosynthesis: Mechanisms, regulation and adaptation. Taylor \& Francis, London, UK.

Strasser, R.J. and M. Tsimilli-Michael. 2001. Stress in plants from daily rhythm to global changes, detected and quantified by JIP test. Chime Nouvelle 75:3321-3326. (SRC).

Struve, D.K. 1993. Effect of copper-treated containers on transplant survival and regrowth of four tree species. J. Environ. Hort. 11:196-199.

Tóth, S.Z., G. Schansker, and R.J. Strasser. 2007. A non-invasive assay of the plastoquinone pool redox state based on the OJIP-transient. Photosynth. Res. 93:193-203.

Tsakaldimi, M., T. Zagas, T. Tsitsoni, and P. Ganatsas. 2005. Root morphology, stem growth and field performance of seedlings of two Mediterranean evergreen oak species raised in different container types. Plant Soil 278 : 85-93.

Tsakaldimi, M.N. and P.P. Ganatsas. 2006. Effect of chemical root pruning on stem growth, root morphology and field performance of the Mediterranean pine Pinus halepensis Mill. Sci. Hort. 109:183-189.

Yamada, M., D. Hidaka, and H. Fukamachi. 1996. Heat tolerance in leaves of tropical fruit crops as measured by chlorophyll fluorescence. Sci. Hort. 67:39-48. 